\title{
Seafood associated human pathogenic non-enveloped viruses
}

\section{Su ürünleri kaynaklı insan patojenik zarfsız virüsleri}

\author{
Bahar Tokur $^{1^{*}}$ - Koray Korkmaz \\ ${ }^{1}$ Ordu University Fatsa Faculty of Marine Sciences Department of Fishery Technology Engineering \\ 52400 Fatsa/ORDU \\ ${ }^{2}$ Ordu University Fatsa Faculty of Marine Sciences Department of Fishery Technology Engineering \\ 52400 Fatsa/ORDU
}

https://orcid.org/0000-0002-7087-5801

https://orcid.org/0000-0003-2940-6592

\section{How to cite this paper:}

Tokur, B. \& Korkmaz, K. (2021). Seafood associated human pathogenic non-enveloped viruses. Ege Journal of Fisheries and Aquatic Sciences, 38(2), 253-262. DOI: 10.12714/egejfas.38.2.16

Abstract: Non-enveloped human pathogenic viruses, highly stable in the environment, can be transmitted by different routes, such as contaminated food and water. The waterborne transmission of non-enveloped viruses to humans causes illnesses when individuals are exposed to contaminated water resources such as agricultural water, drainage, outdoor water, field or subsurface water and even drinking water. In addition to waterborne transmission, viral foodborne transmission may consist because of contagious seafood, through infected food handlers due to inadequate hygienic activities, aerosol containing viruses produced by infected people. Most hazardous non enveloped enteric viruses assocated with water and seafood cause a significant and emerging food safety and public health problem and threat. In this review, norovirus (NoVs), hepatitis $E$ virus (HEV) and hepatitis A (HAV), human adenovirus, rotavirus $A$ and sapovirus are evaluated as seafood associated human pathogenic non-envoleped viruses.

Keywords: Waterborne transmission, seafood borne transmission, pathogenic non-enveloped viruses

Öz: Çevresel ortamda oldukça kararlı olan zarfsız insan patojenik virüsleri, kontamine olmuş gıda ve su gibi farklı yollarla bulaşabilirler. Zarfsız virüslerin insanlara su yoluyla bulaşması, genellikle tarımsal su, drenaj, evsel atık suları, tarım veya yer altı suyu ve hatta içme suyu gibi kirli su kaynaklarına maruz kaldıklarında, hastalıklara neden olur. Su yoluyla bulaşmaya ek olarak, gıda kaynaklı viral bulaşma, virüsleri taşıyan deniz ürünleri, yetersiz hijyenik faaliyetler nedeniyle enfekte olmuş gıda çalışanları ve enfekte kişiler tarafından üretilen aerosol içeren virüslerden kaynaklanabilir. Su ve su ürünleri ile ilişkili zararlı zarfsız enterik virüslerin çoğu, önemli ve ciddi gıda güvenliği ve halk sağlığı sorununa ve tehdidine neden olur. Bu derlemede, su ürünleri ile ilişkili insan patojenik zarfsız virüsler olarak norovirüs (NoVs), hepatit $E$ virüsü (HEV) ve hepatit $A(H A V)$, insan adenovirüs, rotavirüs $A$ ve sapovirüs değerlendirilmiştir.

Anahtar kelimeler: Su kaynaklı bulaş, su ürünleri kaynaklı bulaş, zarfsız patojenik virüsler

\section{INTRODUCTION}

Viruses are a submicroscopic intracellular parasites that, by nature, made up of RNA or DNA genome encapsulated protein shell, varying in size from 15 to $400 \mathrm{~nm}$ and involving just a small number of particles are required to spread disease. Such infections don't happen randomly: each virus group has its own characteristic host diversity and cell selection (Eterpi et al. 2010; Koopmans and Duizer, 2004). A complete sample of the virus is called a virion. The virion 's primary purpose is to transmit the RNA or DNA genome when they infect a host cell. The viral genome, frequently with related basic proteins is packaged into the virion, a symmetric protein capsid. The nucleic acid-associated protein together with the genome are known as nucleoprotein, forms by the association of the nucleocapsid (Gelderblom, 1996).

Among different types of natural water applications, such as agricultural water, drainage, outdoor water, field or subsurface water and drinking water, human pathogenic viruses implicated among water transmission are often observed. (Grabow, 2007; Pinon and Vialette, 2018). It can spread more than 140 forms of pathogenic viruses from the aquatic world (Schwartzbrod and WHO, 1995). All identified waterborne pathogenic viruses present a major threat to public safety in the marine ecosystem which are spread mainly through fecal-oral routes, which is regularly released into coastal and estuarine environments by the runoff of processed and untreated wastewater (Rao et al., 1986; Griffin et al., 2003; Kovać et al., 2009) and urine, and respiratory secretions from the infected host which enter into sewage water (Wang et al., 2018). The average viral concentration in wastewater changes between $10^{2}$ and $10^{3}$ PFU ${ }^{1-1}$, and it can be estimated at between $10^{1}$ and $10^{2}$ PFU $1^{-1}$ in treated wastewater and $10^{3} \mathrm{PFU} \mathrm{Kg}^{-1}$ in treated sludge, depending on the type of treatment and its yield. According to the intensity of faecal pollution, the concentration in the surface water changes, but can be determined at $10^{1} \mathrm{PFU} 1^{-1}$ in river water and between 1 and 10 PFU $1^{-1}$ in contaminated sea water (Chang et al., 1995). Humans can be infected the pathogenic virus infected in the fecal contaminated water through production in watercourses by collecting, handling, preparation, processing, carrying and storage chain (Blumenthal et al., 2000; Elbashir et al., 2018; Lee and 
Rangdale, 2008; Schwartzbrod and WHO, 1995). These polluted ecosystems will end up with unhealthy seafood.

Worldwide an estimated 8 billion per year gastrointestinal disease occur annually (Chan et al., 2019). Viruses associated with acute gastroenteritis, include diarrhea, fever, headache, vomiting, abdominal cramps, and myalgia, may occur as a result of contamination of the marine environment with feces (Adelodun et al., 2020; Koopman et al., 1982). Viral pathogens from water environment have also been reported which include norovirus (NoVs), hepatitis E virus (HEV) and hepatitis $A(H A V)$, human adenovirus, rotavirus $A$ and sapovirus (Bosch et al., 2005; Joshi et al., 2019; WHO, 2006). This work will focus on different human pathogenic nonenveloped viruses associated with seafood and their characteristics.

\section{Human pathogenic non-enveloped viruses}

\section{Noroviruses}

Norovirus is a small organized RNA virus, and a class known as human pathogens belong to the family Caliciviridae. Virus particles are 27-37 nm in diameter and unwrapped, which cause their high tenacity and disinfection resistance (Bachofen, 2018). The NoV genome of approximately $7.5 \mathrm{~kb}$ is positive-sense single-stranded RNA with three free read frames encoding both structural and non-structural proteins (Campos and Lee, 2014). The viral protein 1, the capsid protein, is the viral capsid's most significant component, while the viral protein 2 is inserted within the capsid at low copy numbers (Figure 1).

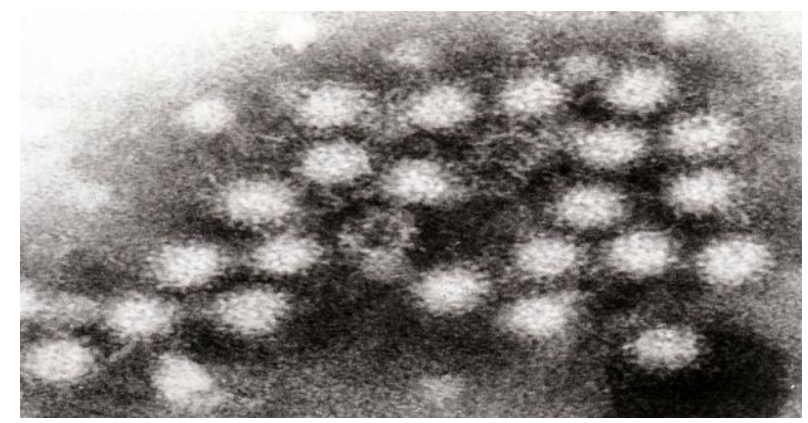

Figure 1.Transmission electron micrograph of Norovirus particles in feces by Graham Beards at English Wikipedia ( CC BY 3.0. https://commons. wikimedia.org/w/index.php?curid=5736176

Norovirus (NoV) is well-known to be the primary causative agent of seafood transmitted illness (Bachofen, 2018; Grabow,2007; Li et al., 2014; Terregino and Arcangeli, 2017) and the emergence in viral gastroenteritis outbreaks is a global safety issue which is also blamed for economic losses (Kobayashi et al., 2019; Pavoni et al., 2013). Several geographic areas worldwide have been confirmed to have numerous seafood associated outbreaks of various norovirus strains (Stals et al., 2013; Vidal et al., 2005). The spread of NoV is primarily due to its low infectious dose is sufficient to cause infection and gastroenteritis needed for the infection
(Khora, 2018; Koopmans et al., 2002; Teunis et al., 2008). The long-term survival and longevity of NoV on infected surfaces used in food processing areas often lead significantly to transmission of the disease (Moorman, 2017).

The main route for norovirus transmission is harvesting or catching of seafood from faecally contaminated waters (Butt et al., 2004; Campos and Lee, 2014; Terregino and Arcangeli, 2017), NoV-infected food handling (Grabow 2007; Li et al. 2014; Widdowson et al., 2000), contaminated surfaces and utensils used in food preparation areas because of the longterm stability and persistence of NoV (Cheesbrough et al., 2000; Evans et al., 2002; Lamhoujeb et al., 2009; Mattison et al., 2007; Sharp et al., 2012; Tuladhar et al., 2013). Hardstaff et al. (2018) stated personnel working as food handler (mostly in the kitchen) were tested for NoV in 44 of $51(86 \%)$ outbreaks and food handlers, the median proportion of positive samples, showed $46 \%$ (interquartile range of $25-$ $76 \%$ ). In fact, inadequate preparation, such as steaming clams, has led to disease and outbreaks even before they expand rather than to higher temperatures that destroy noroviruses (Centers for Disease Control and Prevention, 2010; DuPont, 1986; Le Guyader and Atmar, 2007; Morse et al., 1986). Consumption of contaminated raw/undercooked oysters are at risk for secondary infection of $\mathrm{NoV}$ in household contacts (Guix et al., 2019). Cooking shellfish (e.g. by steaming) can not inactivate the virus, so after ingestion of cooked shellfish, incidents of infection have occurred (Le Guyader and Atmar, 2007; Li et al., 2014; McDonnell et al., 1997). In comparison, NoV is often immune to certain commercial food storage practices and can withstand boiling, freezing, acidification, decreased water movement and changed packaging environment (Baert et al. 2009).

Shellfish, in particular moulds, clams and oysters, crabs, prawns, finfish, shirmps are usually implicated in seafoodborne norovirus outbreaks because of their feeding patterns as filter feeders and their capacity to absorb the virus from polluted water (Das et al., 2020; Woods et al., 2016). Throughout this filter feeding, bacteria and viruses may be stored and accumulated in their bodies due to land-based waste outflow or harvester runoff disposal (Bellou et al., 2013; Kohn et al., 1995; Le Guyader et al., 2006). Oysters are capable of great flesh and intestine bioaccumulation at amounts up to 99 times greater than the local waters during the autumn / winter season (Burkhardt and Calci, 2000) and remain contagious well after depuration (McLeod et al., 2009). NoV, which can be insufficiently removed by standard decontamination procedures (McLeod et al., 2017; MuniainMujika et al., 2002) the result is gastroenteritis outbreaks after consumption of shellfish (Le Guyader et al., 2006; Le Guyader et al., 2008; Webby et al., 2007). Le Guyader et al. (2008) and Doré et al. (2010) both stated that NoV was still measureable in some samples after three to four weeks of purification in open seawater. This may suggest that low levels of NoV in oysters purified for three to four weeks in clean open seawater is small risk to consumers. However, 
Doré et al. (1998) stated that a the low levels of NoV particles may be able to inducing infection of NoV in oysters after four weeks of purification (McLeod et al., 2017).

\section{Hepatitis A virus}

Hepatitis A virus (HAV) has an assRNA (+) genome of 7.5 $\mathrm{kb}$ size and a Picornaviridae family member belonging to the Hepatovirus class (2). Particles of the virus come in two versions: naked, unenveloped $27 \mathrm{~nm}$ diameter icosahedral virions with a protein capsid surrounding them (Butt et al., 2004; Feng et al., 2013). Electron micrograph of "Hepatovirus $A$ " virions is shown in Figure 2

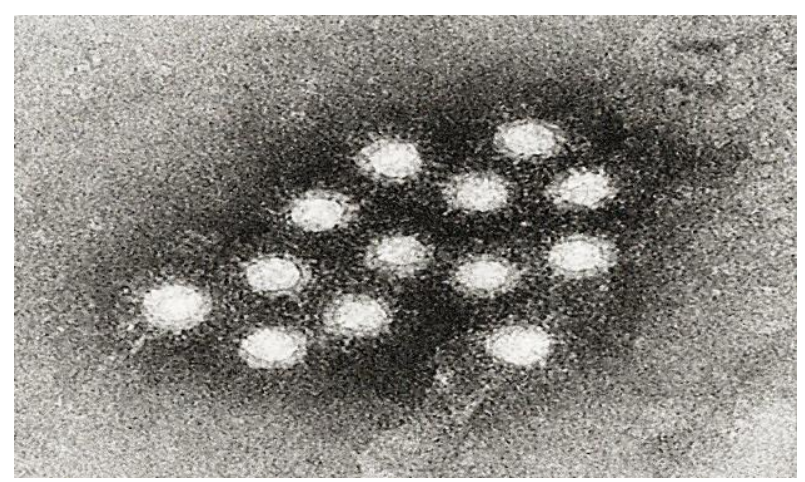

Figure.2. Electron micrograph of "Hepatovirus A" virions. This media comes from the Centers for Disease Control and Prevention's Public Health Image Library (PHIL), with identification number \#2739 (https://commons.wikimedia.org/wiki/File:Hepatitis_A_viru s_02.jpg\#/media/File:Hepatitis_A_virus_02.jpg)

Hepatitis $A$ is the most severe virus infection related to the consumption of seafood (Grabow, 2007; 8; Khora, 2018; Iwamato et al., 2010). The WHO (2015) reports that 14 million foodborne infections and 27,731 fatalities in 2010 were triggered by hepatitis A virus (HAV) (Kirk et al., 2015). Incidence of contamination ranges across areas of the world, with the largest incidence in developed nations where there could be inadequate water management and hygiene procedures (Rodriguez-Lazaro et al., 2012). In 1955, when 629 cases were connected with oyster ingestion, the first HAV-linked seafood-borne epidemic involving oysters was reported in Sweden (La Rosa et al., 2012; Lindberg-Braman, 1956). 1988 witnessed the biggest outbreak in Shanghai, China, in which more than 288,000 people were poisoned after consuming fresh or poorly cooked clams (Butt et al., 2004). Between 1986 and 2012, 46 HAV outbreaks were reported and linked to seafood vehicles worldwide, such as oysters, clams, moulds and cockles (Bellou et al., 2013).

Bivalve molluscs, such as soft clams, hard clams, moulds and oysters, have been infected with HAV outbreaks and pollution most often happens when shellfish growing areas become polluted with human sewage (Khora, 2018). Through successful filtration, shellfish accumulate the virus many times in their tissue. The infectious dosage is small, maybe 10-100 virus particles, which is undoubtedly the explanation why shellfish collected from areas were feasibly infected (Butt et al., 2004). In fact, shellfish are consumed with their digestive tracts in place, unlike many other seafoods. Shellfish, mostly consumed raw or lightly cooked, may also protect viruses by adequate cooking, unlike other foods (Patwardhan, 2019).

Hepatitis A virus transmission is spread by consumption of fecal polluted water and/or seafood, inadequate ventilation, bad personal hygiene and close contact with an infected person (including asymptomatic carriage) (Bosch 1998; Butt et al., 2004; Tallon et al., 2008; Richards, 2013; WHO, 2016). In the primary instances, the most significant risk factor was the intake of raw seafood, during interaction with individuals (Germinario et al., 2000).

The HAV has environmental stability, which makes it viable in water or on fomites for many weeks and including freezing, heat, chemicals, and desiccation (Khora, 2018). For instance, the virus can keep living for a long time in tap water (up to 60 days), in river water (over 6 weeks), in groundwater (over 8 weeks) and in sea water (up to 30 weeks) (Crance et al., 1998; Enriquez et al., 1995; Sobsey, 1989; Springthorpe et al., 1993). In fact, hepatitis A virus is heat-resistant and can tolerate steaming, so proper cooking of seafood diminishes the risk of ingestion of live hepatitis A. Since shellfish is widely prepared in ways that are inadequate to inactivate the virus, several preventive techniques are aimed to manage the contamination before the food is processed (Iwamato et al., 2010).

\section{Hepatitis E virus}

Hepatitis E virus (HEV) as is a a tiny (32-34 nm) singlestranded, positive-sense RNA virus coated with protein classified in the family Hepeviridae, RNA molecule of approximately $7.2 \mathrm{~kb}$ in size (Khora, 2018) and comprising of four known Genotypes (1-4), at least two new putative mammalian HEV genotypes and one floating genus of HEV avian (Yugo and Meng, 2013; Van der Poel, 2014). Electron micrograph of Hepatitis E viruses (HEV) is given in Figure 3.

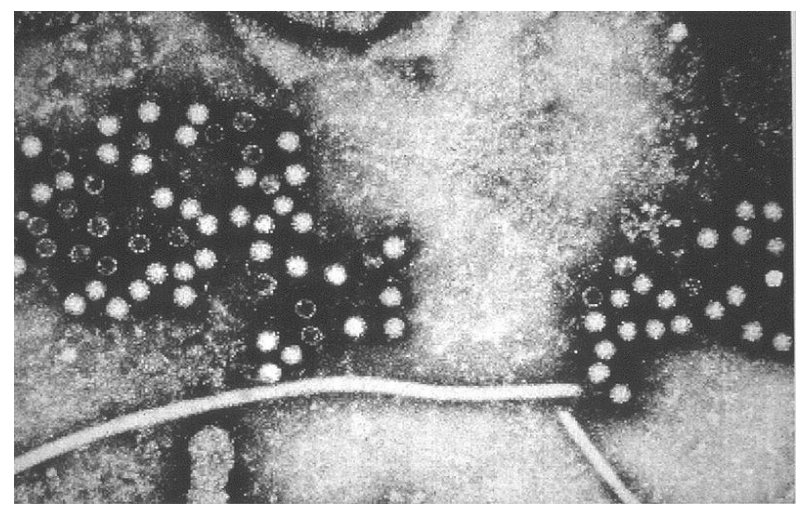

Figure3. Electron micrograph of Hepatitis E viruses (HEV). This media comes from the Centers for Disease Control and Prevention's Public Health Image Library (PHIL), with identification number \#5605,

https://commons. wikimedia.org/w/index.php?curid $=18825$ 68 
Hepatitis $E$ virus (HEV) is a virus that causes acute hepatitis outbreaks and endemics in humans, which can be transmitted mainly to people and other animals from fecal-oral routes and animals (Sooryanarain and Meng, 2019). Unfortunately, this ensures that some species may act as reservoirs for HEV strains that infect humans (Grabow, 2007). Insufficient management and storage of wastewater, the usage of contaminated river water for coomon activities and contamineted of drinking and irrigation water contribute to numerous epidemics in developed countries (Ceylan et al., 2003; Fenaux et al., 2019).

HEV can easily pollute the surface water, entering through food production chains, especially via shellfish cultivation areas and irrigation waters function as a threat to public health (Di Cola et al. 2020). The surface water's quality directly affects people using the source as drinking water, and intense agricultural activities result in high levels of viruses in these sources (Yugo and Meng, 2013).

Coastal waters can also be polluted with HEV, contributing to the aggregation of the virus in shellfish 's digestive tissues, which presents a possibility of human infection by ingestion (Yugo and Meng, 2013; Van der Poel, 2014). Very commonly, moulds, cockles and oysters are consumed raw or partially fried, and HEV is stable at $\mathrm{pH} 2$ to 9 (Wolff et al., 2020), frozen for more than 10 years (Emerson et al., 2005) and fresh, undercooked or partially steamed infected seafood will pass HEV to consumers (Crossan et al., 2012; Namsai et al., 2011). People who travel to hyperendemic and endemic areas of the world are at elevated risk of contamination with HEV from polluted water and seafood, in which developed countries are not excluded (Yugo and Meng, 2013; Zuckerman, 2003). Said et al. (2009) reported severe HEV infections in 33 participants on a 2008 world cruise caused by shellfish (crabs, prawns, moulds, lobsters, and scallops) and mixed seafood (a combination of shrimp, mussels, salmon, hake, cod, and squid). Recent studies have been showed that HEV infections may be associated with shellfish consumption (Rivadulla et al., 2019; Webb et al., 2020; Zhang et al., 2017).

\section{Rotavirus A}

Rotaviruses (RVs), a member of the genus Rotavirus of the Reoviridae family, consisting of a rectangular segmented double-stranded RNA genome in a non-enveloped icosahedral capsid 60-80 nm in diameter (Gerba et al., 1996; Grabow, 2007; Estes, 2001). The genome of $16-27 \mathrm{~kb}$ is bound by a triple layer of capsid covered by a double protein coat (Sattar et al., 1994). The capsid has a unique double layer with spikes between the layers giving it the wheel-like outlook (Latin "rota") hence the name rotavirus is derived from the Latin meaning rota (wheel) (Gerba et al., 1996; Grabow, 2007; Khora, 2018). Electron Micrographs of Rotaviruses is shown in Figure 4.

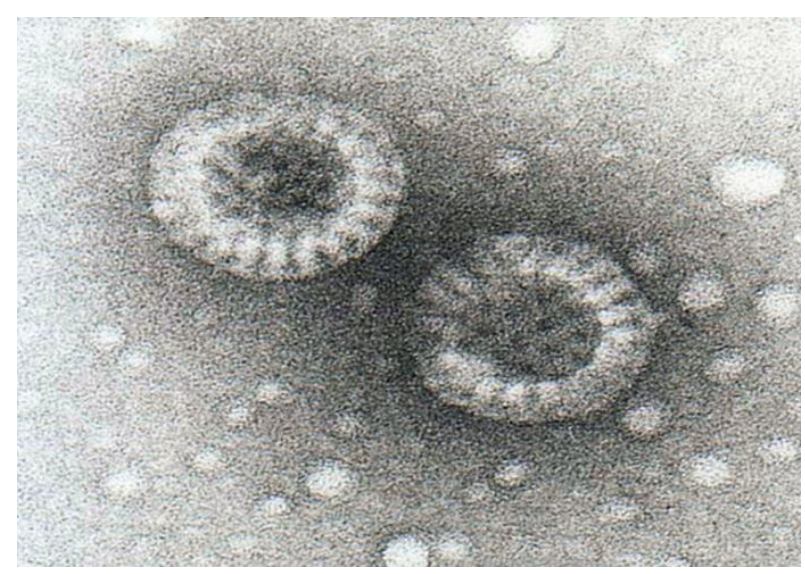

Figure 4. Electron Micrographs of Rotaviruses by $\mathrm{Dr}$ Graham Beards at en.wikipedia, CC BY-SA 4.0,

https://commons. wikimedia.org/w/index. php?curid=1601 4758

Given the global adoption of rotavirus vaccines, RVA is the main agent of acute gastroenteritis in infants worldwide, with many deaths / year cases (> 200,000), especially in lowincome and undeveloped countries (Crawford et al., 2017). In 2003,114 million cases of rotavirus infection were recorded worldwide in children who were less than 5 years of age, 24 million of which needed outpatient visits and 2,3 million of which needed to be hospitalized. (Parashar et al., 2003). Rotaviruses are released from the feces of infected people in exceptionally high numbers (up to $1010 \mathrm{~g}-1$ ) and can remain in the atmosphere for long periods of time (Carter, 2005) contributing to the potential for pollution of recreational and drinking water. (Gerba et al., 1996). The infectious dose is estimated at between 100 and 1000 particles of the virus (Ward et al., 1986). The viral particles are extremely robust and dangerously contagious to harsh ambient conditions. Despite exceptionally high levels of faecal excretion and confirmation of the possibility of waterborne transmission, the predominant route of transmission is via the fecal-oral route under poor hygienic conditions. (Khora, 2018; MaganaArachch and Wanigatunge, 2020). Several waterborne rotavirus outbreaks which have caused illnesses in both adults and children (Chia et al., 2018; Tozan et al., 2016; Sattar, 2001).

RoV has been frequently detected in found in both freshwater and marine water sources and can also be concentrated by shellfish with higher prevalences and levels (Cook et al. 2004; Lees, 2000; Lodder and de Roda Husman, 2005; Prevost et al., 2015; Souza et al., 2018). Keller et al. (2013), found genomes of Rotavirus in Brazil, with a range of 76 and $88 \%$ of water samples and $100 \%$ of mussel samples. Quiroz-Santiago et al. (2014) detected that shellfish grown in China is infected by Rotavirus with a $7 \%$ ratio identified. Shellfish bioaccumulate viruses in their gills, digestive glands, and other tissues during filter feeding (Asahina et al., 2009; Schwab et al., 1998; Wang et al., 2008). 
Rotavirus also occurs in infected and non-polluted fresh water (Hurst and Gerba, 1980). Amoroso et al. (2020) examined a two-phase kinetic virus elimination with a high reduction in the first $24 \mathrm{~h}$ of depuration and rotavirus were completely removed after 5 days in experimentally contaminated Mytilus galloprovincialis.

\section{Human Adenovirus}

Adenoviruses are double-stranded, non-enveloped, icosahedral DNA viruses (Bosch, 2007). Human adenoviruses (HAds) belong to the genus Mastadenovirus in the Adenoviridae family consisting of a double-stranded DNA genome in a non-enveloped icosahedral capsid with a diameter varying from 80 to $110 \mathrm{~nm}$ (Figure 5).

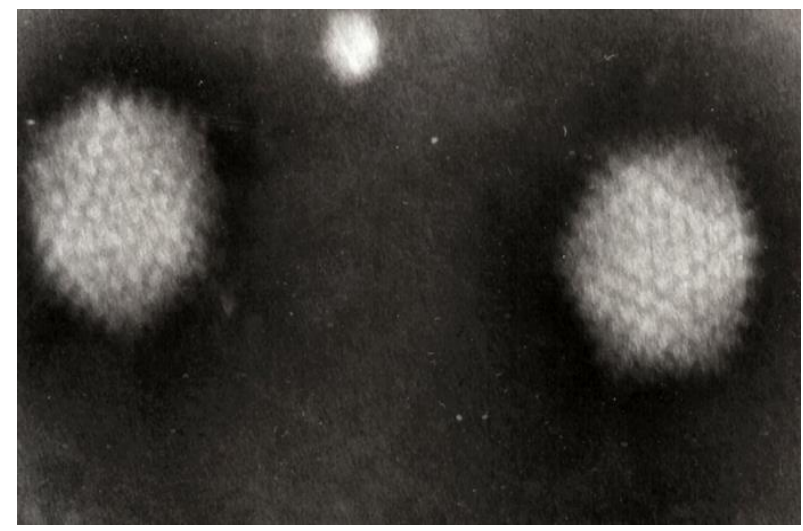

Figure 5. Transmission electron micrograph of two Adenovirus particles By GrahamColm at English Wikipedia, CC BY 3.0,

https://commons. wikimedia.org/w/index. php?curid=3921 907

Adenoviruses are linked to a number of human diseases and were responsible for waterborne outbreaks (Crabtree et al., 1997). There have been many cases of waterborne recreational outbreaks attributed to adenovirus within years (Bonadonna and La Rosa, 2019; Koopmans et al., 2017; Zhang et al., 2016). These viruses have been commonly seen in riversides, coast waters, swimming pool waters, and drinking water supplies all over the world where they may survive until four months (Jiang et al., 2001; Jiang, 2006). Adenovirus prevents environmental deterioration and water treatment rather than other measures of pollution (De Moraes Tavares et al., 2005; Griffin et al., 2008; Luz et al., 2015; Jiang et al., 2007).

Adenovirus can be transmitted either directly from person to person or via the fecal-oral route that can result from the ingestion of polluted water during outdoor practices or from the processing of shellfish obtained from polluted waters and contaminated food and liquid intake (Benabbes et al., 2021; Gyawali and Hewitt, 2020).

Formiga-Cruz et al. (2002) reported that, with respect to the existence of human enteric viruses, Adenovirus was the most wide spreading virus group found in oyster (C. gigas and
O. edulis) and mould (M. edulis and $M$. galloprovincialis) samples across Europe. Choo and Kim (2006) reported that $50.9 \%$ of oysters harvested from the wholesale fishing industry in Noryangjin were infected with contagious adenovirus. Ghalyoun and Alçay (2018) detected adenovirus before the fishing season ended in $46.15 \%$ of the musk sample from three separate locations in Istanbul. Luz et al. (2015) reported that the findings of the analysis revealed substantial bioaccumulation of adenoviruses in shrimp, demonstrating the magnitude of fecal pollution 's effect on aquatic environments. In $18.6 \%$ of shellfish tests from the Norwegian coast, Myrmel et al. (2004) have found Adenovirus with more accurate tests in the winter season.

\section{Sapovirus}

It is a small $(27-40 \mathrm{~nm})$ nonenveloped RNA virus which belongs to the Caliciviridae family (like NoV) and forms its own genus. Similar to NoV, only observed sapoviruses (SaV) in 1977 was extremely immune to negative environmental factors (Grabow, 2007), usually infecting humans (HuCVs), as well as two other genera synonymous with animal diseases, including primates, birds, reptiles and insects (Figure 6)

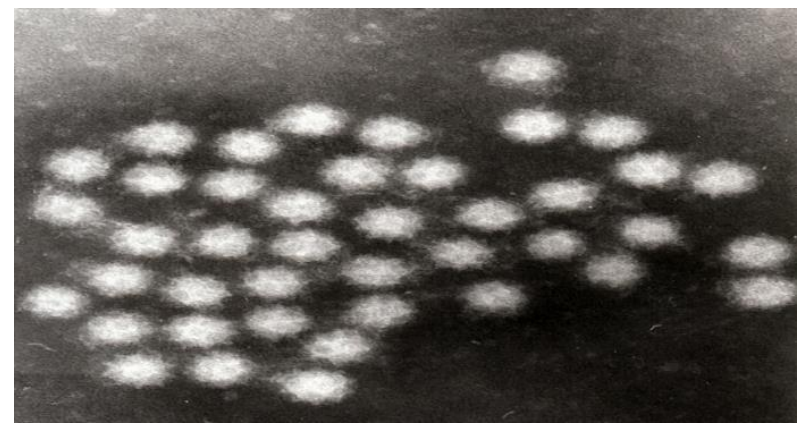

Figure 6. Transmission electron micrograph of Sapporo viruses By Graham Beards at English Wikipedia, CC BY 3.0, https://commons. wikimedia.org/w/index. php?curid $=56088$ 018

$\mathrm{SaV}$ is spread via the fecal-oral path discharge into environmental waters and collected by shellfish (i.e., or oysters clams) (Hansman et al., 2007; Khora, 2018; Nakagawa-Okamoto et al., 2009; Oka et al., 2015), as well as in contaminated food related with the intake of shellfish (Nakagawa-Okamoto et al., 2009), water, materials, and human interactions. Lizuka et al. (2010) reported that SaV was found in fecal specimens of 17 individuals who consumed restaurant food and one asymptomatic food handler, as well as in stripped shellfish and residual liquids in shellfish containers, which triggered a gastroenteritis spread in a restaurant, June 2008. Ueki et al. (2010) show that SaV can be accumulated in oysters which are grown in an estuary in Japan that receives treated sewage. During a three-year period (2015-2017), Fusco et al. (2019) detected sapovirus (SaV; 18.8\%) in bivalve mollusc samples from three littoral zones of the Campania region in South West Italy. 


\section{CONCLUSION}

Seafoodborne and waterborne viruses may exist in any form of untreated water due to pollution induced by faecal content of human or animal origin and directly infected through interaction with body secretions and fluids containing contagious viral particles or indirectly by aerosols or other polluted fomites. Thus, the human pathogenic viruses can infect seafood and its products anytime from water and food environments. Non-enveloped viruses are commonly known to have a greater tolerance to desiccation and are therefore harder to transmit than viruses with an envelope tag, which often correlates to their mode of transmission. For this cause, a significant danger is the intake of food that is cooked only minimally before consumption or eaten with fresh vegetables, shellfish or other conventional meat specialities. When the food can't be accurately decontaminated during processing, it is essential to prepare the food such as cooking.

\section{REFERENCES}

Adelodun, B., Ajibade, F.O., Ighalo, J.O., Odey, G., Ibrahim, R.G., Kareem, K.Y. \& Adeniran, K.A. (2020). Assessment of socioeconomic inequality based on virus-contaminated water usage in developing countries: a review. Environmental Research, 110309.

DOI: 10.1016/j.envres.2020.110309

Amoroso, M.G., Langellotti, A.L., Russo, V., Martello, A., Monini, M., Di Bartolo, I. \& Fusco, G. (2020). Accumulation and Depuration Kinetics of Rotavirus in Mussels Experimentally Contaminated. Food and Environmental Virology, 12(1), 48-57. DOI: $10.1007 / \mathrm{s} 12560-019-09413-0$

Asahina, A.Y., Lu, Y., Wu, C., Fujioka, R.S. \& Loh, P.C. (2009). Potential biosentinels of human waste in marine coastal waters: Bioaccumulation of human noroviruses and enteroviruses from sewage-polluted waters by indigenous mollusks. Journal of Virological Methods, 158(1-2), 46-50. DOI: 10.1016/j.jviromet.2009.01.013

Bachofen, C. (2018). Selected viruses detected on and in our food. Current Clinical Microbiology Reports, 5(2), 143-153. DOI: $10.1007 /$ s40588-018-0087-9

Baert, L., Debevere, J. \& Uyttendaele, M. (2009). The efficacy of preservation methods to inactivate foodborne viruses. International journal of food microbiology, 131(2-3), 83-94. DOI: 10.1016/j.ijfoodmicro.2009.03.007

Bellou, M., Kokkinos, P. \& Vantarakis, A. (2013). Shellfish-borne viral outbreaks: a systematic review. Food and Environmental Virology, 5(1), 13-23. DOI: 10.1007/s12560-012-9097-6

Benabbes, L., Anga, L., Faouzi, A., Rhaissi, H. \& Nourlil, J. (2021). Detection of human enterovirus and adenovirus in shellish collected in Morocco Mediterranean Coast. Journal of Microbiology, Biotechnology and Food Sciences, 2020, 97-100.

Blumenthal, U.J., Mara, D.D., Peasey, A., Ruiz-Palacios, G. \& Stott, R. (2000). Guidelines for the microbiological quality of treated wastewater used in agriculture: recommendations for revising WHO guidelines. Bulletin of the World Health Organization, 78, 1104-1116.

Bonadonna, L. \& La Rosa, G. (2019). A review and update on waterborne viral diseases associated with swimming pools. International journal of environmental research and public health, 16(2), 166. DOI: 10.3390/ijerph16020166

Bosch, A., (1998). Human enteric viruses in the water environment. A minireview. Int. Microbiol. 1, 191-196.

Bosch, A., Abad, F.X. \& Pintó, R.M. (2005). Human pathogenic viruses in the marine environment. In oceans and health: pathogens in the marine environment (pp. 109-131). Springer, Boston, MA. DOI: 10.1007/0-38723709-7_5

Bosch, A., (2007). Human viruses in water. Elsevier Academic Press, Amsterdam, The Netherlands

Burkhardt, W. \& Calci, K.R. (2000). Selective accumulation may account for shellfish-associated viral illness. Applied and Environmental Microbiology, 66(4), 1375-1378. DOI: 10.1128/AEM.66.4.1375-1378.2000

Butt, A.A., Aldridge, K. E. \& Sanders, C. V. (2004). Infections related to the ingestion of seafood Part I: viral and bacterial infections. The Lancet

infectious diseases, 4(4), 201-212.

DOI: 10.1016/S1473-3099(04)00969-7

Campos, C.J. \& Lees, D.N. (2014). Environmental transmission of human noroviruses in shellfish waters. Applied and Environmental Microbiology, 80(12), 3552-3561. DOI: 10.1128/AEM.04188-13

Carter, M.J., (2005). Enterically infecting viruses: pathogenicity, transmission and significance for food and waterborne infection. Journal of Applied Microbiology, 98, 1354-1380. DOI: 10.1111/j.1365-2672.2005.02635.x

Centers for Disease Control and Prevention (2010) Norovirus: Technical fact sheet.

http://www.cdc.gov/ncidod/dvrd/revb/gastro/norovirus.htm. Accessed 01 March 2011

Ceylan, A., Ertem, M., Ilcin, E. \& Ozekinci, T. (2003). A special risk group for hepatitis $E$ infection: Turkish agricultural workers who use untreated waste water for irrigation. Epidemiology \& Infection, 131(1), 753-756. DOI: $10.1017 /$ S0950268803008719

Chan, J.S.H., Chao, A.C.W., Cheung, V.C.H., Wong, S.S.K., Tang, W., Wu, J.C.Y. \& Ng, S.C. (2019). Gastrointestinal disease burden and mortality: A public hospital-based study from 2005 to 2014. Journal of gastroenterology and hepatology, 34(1), 124-131. DOI: 10.1111/jgh.14377

Chang, A.C., Page, A.L. \& Asano, T. (1995). Developing human healthrelated chemical guidelines for reclaimed wastewater and sewage sludge applications in agriculture (No. WHO/EOS/95.20). World Health Organization.

Cheesbrough, J.S., Green, J., Gallimore, C.I., Wright, P.A. \& Brown, D.W.G. (2000). Widespread environmental contamination with Norwalk-like viruses (NLV) detected in a prolonged hotel outbreak of gastroenteritis. Epidemiology \& Infection, 125(1), 93-98. DOI: $10.1017 /$ S095026889900432X

Chia, G., Ho, H.J., Ng, C.G., Neo, F. J.X., Win, M.K., Cui, L. \& Chow, A. (2018). An unusual outbreak of rotavirus G8P [8] gastroenteritis in adults in an urban community, Singapore, 2016. Journal of Clinical Virology, 105, 57-63. DOI: 10.1016/j.jcv.2018.06.004

Choo, Y.J. \& Kim, S.J. (2006). Detection of human adenoviruses and enteroviruses in Korean oysters using cell culture, integrated cell culturePCR, and direct PCR. The Journal of Microbiology, 44(2), 162-170.

Cook, N., Bridger, J., Kendall, K., Gomara, M.I., El-Attar, L. \& Gray, J. (2004). The zoonotic potential of rotavirus. Journal of Infection, 48(4), 289-302. DOI: 10.1016/j.jinf.2004.01.018

Crabtree, K.D., Gerba, C.P., Rose, J.B. \& Haas, C.N. (1997). Waterborne adenovirus: a risk assessment. Water Science and Technology, 35(1112), 1-6. DOI: 10.1016/S0273-1223(97)00225-4

Crance, J.M., Gantzer, C., Schwartzbrod, L. \& Deloince, R. (1998). Effect of temperature on the survival of hepatitis $A$ virus and its capsidal antigen in synthetic seawater. Environmental Toxicology and Water Quality: An International Journal, 13(1), 89-92.

DOI: 10.1002/(SICI)1098-2256(1998)13:1<89::AID-TOX7>3.0.CO;2-3 
Crawford, S.E., Ramani, S., Tate, J.E., Parashar, U.D., Svensson, L. \& Hagbom, M. (2017). Rotavirus infection. Nature Reviews Disease Primers, 3(1), 1-16. DOI: 10.1038/nrdp.2017.83

Crossan, C., Baker, P.J., Craft, J., Takeuchi, Y., Dalton, H.R. \& Scobie, L. (2012). Hepatitis E virus genotype 3 in shellfish, United Kingdom. Emerging Infectious Diseases, 18(12), 2085 DOI: 10.3201/eid1812.120924

Das, O., Lekshmi, M., Kumar, S. \& Nayak, B.B. (2020). Incidence of norovirus in tropical seafood harbouring fecal indicator bacteria. Marine Pollution Bulletin, 150, 110777. DOI: 10.1016/j.marpolbul.2019.110777

De Moraes Tavares, T., De Paula Cardoso, D.D.D. \& De Brito, W M.E.D. (2005). Virus Entérıcos Veiculados Por Água: Aspectos Mıcrobıológıcos E Decontrole De Qualıdade Da Água. Revista De Patologia Tropical/Journal of Tropical Pathology, 34(2), 85-104

Di Cola, G., Fantilli, A.C., Pisano, M.B. \& Ré, V.E. (2020). Foodborne transmission of hepatitis $A$ and hepatitis $E$ viruses: a literature review. International Journal of Food Microbiology, 108986. DOI: 10.1016/j.ijfoodmicro.2020.108986

Doré, W.., Henshilwood, K. \& Lees, D.N. (1998). The development of management strategies for control of virological quality in oysters. Water Science and Technology, 38(12), 29-35.

DOI: 10.1016/S0273-1223(98)00796-3

Doré, B., Keaveney, S., Flannery, J. \& Rajko-Nenow, P. (2010). Management of health risks associated with oysters harvested from a norovirus contaminated area, Ireland, February-March 2010. Eurosurveillance, 15(19), 19567.

DuPont, H.L. (1986). Consumption of raw shellfish-is the risk now unacceptable?.The New England Journal of Medicine, 314, 707-708. DOI: 10.1056/NEJM198603133141109

Elbashir, S., Parveen, S., Schwarz, J., Rippen, T., Jahncke, M. \& DePaola, A. (2018). Seafood pathogens and information on antimicrobial resistance: A review. Food Microbiology, 70, 85-93. DOI: 10.1016/j.fm.2017.09.011

Emerson, S.U., Arankalle, V.A. \& Purcell, R.H. (2005). Thermal stability of hepatitis E virus. The Journal of Infectious Diseases, 192(5), 930-933. DOI: $10.1086 / 432488$

Enriquez, C.E., Hurst, C.J. \& Gerba, C.P. (1995). Survival of the enteric adenoviruses 40 and 41 in tap, sea, and waste water. Water Research, 29(11), 2548-2553. DOI: 10.1016/0043-1354(95)00070-2

Estes, M.K. (2001). Rotaviruses and their replication. Fields Virology. 4edn, pp. 1747-1785. (Eds) Knipe D M, Howley P M, Grifûn D E, Lamb R A, Martin M A, Roizman B.. Philadelphia

Eterpi, M., McDonnell, G. \& Thomas, V. (2010). Virucidal activity of disinfectants against parvoviruses and reference viruses. Applied Biosafety, 15(4), 165-171. DOI: 10.1177/153567601001500402

Evans, M.R., Meldrum, R., Lane, W., Gardner, D., Ribeiro, C.D., Gallimore, C.I. \& Westmoreland, D. (2002). An outbreak of viral gastroenteritis following environmental contamination at a concert hall. Epidemiology and Infection, 129(2), 355-360. DOI:10.1017/S0950268802007446

Fenaux, H., Chassaing, M., Berger, S., Gantzer, C., Bertrand, I. \& Schvoerer, E. (2019). Transmission of hepatitis $E$ virus by water: An issue still pending in industrialized countries. Water research, 151, 144-157. DOI: 10.1016/j.watres.2018.12.014

Feng, Z., Hensley, L., McKnight, K.L., Hu, F., Madden, V., Ping, L., ... \& Lemon, S.M. (2013). A pathogenic picornavirus acquires an envelope by hijacking cellular membranes. Nature, 496(7445), 367-371. DOI: $10.1038 /$ nature 12029

Formiga-Cruz, M., Tofino-Quesada, G., Bofill-Mas, S., Lees, D.N., Henshilwood, K. \& Allard, A.K. (2002). Distribution of human virus contamination in shellfish from different growing areas in Greece, Spain, Sweden, and the United Kingdom. Applied and Environmental Microbiology, $\quad 68(12), \quad 5990-5998 . \quad$ DOI: 10.1128/AEM.68.12.59905998.2002
Fusco, G., Anastasio, A., Kingsley, D.H., Amoroso, M.G., Pepe, T. \& Fratamico, P.M. (2019). Detection of hepatitis a virus and other enteric viruses in shellfish collected in the gulf of Naples, Italy. International Journal of Environmental Research and Public Health, 16(14), 2588DOI: 10.3390/jijerph16142588

Gelderblom, H.R. (1996). Structure and classification of viruses. In Medical Microbiology. 4th edition. University of Texas Medical Branch at Galveston.

Gerba, C.P., Rose, J.B. \& Haas, C.N. (1996). Sensitive populations: who is at the greatest risk?. International Journal of Food Microbiology, 30(1-2), 113-123.DOI: 10.1016/0168-1605(96)00996-8

Germinario, C., Lopalco, P.L., Chicanna, M. \& Da Villa, G. (2000). From hepatitis $B$ to hepatitis $A$ and $B$ prevention: the Puglia (Italy) experience. Vaccine, 18, S83-S85.DOI: 10.1016/S0264-410X(99)00473-9

Ghalyoun, F. \& Alçay, A.Ü. (2018). Investigation of Rotavirus, Adenovirus and Astrovirus in Mussels and Shrimps Using Multiplex Real-time PCR. Kafkas Üniversitesi Veteriner Fakültesi Dergisi, 24(5), 761-767. DOI: $10.9775 / \mathrm{kvfd} .2018 .19997$

Grabow, W.O. (2007). Overview of health-related water virology. Perspectives in Medical Virology, 17, 1-25. DOI: $10.1016 /$ S0168-7069(07)17001-4

Griffin, D.W., Donaldson, K.A., Paul, J.H. \& Rose, J.B. (2003). Pathogenic human viruses in coastal waters. Clinical Microbiology Reviews, 16(1), 129-143. DOI: 10.1128/CMR.16.1.129-143.2003

Griffin, J.S., Plummer, J.D. \& Long, S.C. (2008). Torque teno virus: an improved indicator for viral pathogens in drinking waters. Virology Journal, 5(1), 1-6. DOI: 10.1186/1743-422X-5-112

Guix, S., Pintó, R. M. \& Bosch, A. (2019). Final consumer options to control and prevent foodborne Norovirus infections. Viruses, 11(4), 333. DOI: $10.3390 / v 11040333$

Gyawali, P. \& Hewitt, J. (2020). Faecal contamination in bivalve molluscan shellish: can the application of the microbial source tracking method minimise public health risks?. Current Opinion in Environmental Science \& Health, 16, 14-21. DOI: 10.1016/j.coesh.2020.02.005

Hansman, G.S., Oka, T., Okamoto, R., Nishida, T., Toda, S. \& Noda, M. (2007). Human sapovirus in clams, Japan. Emerging Infectious Diseases, 13(4), 620. DOI: 10.3201/eid1304.061390

Hardstaff, J.L., Clough, H.E., Lutje, V., McIntyre, K.M., Harris, J.P. \& Garner, P. (2018). Foodborne and food-handler norovirus outbreaks: a systematic review. Foodborne Pathogens and Disease, 15(10), 589-597. DOI: $10.1089 / \mathrm{fpd} .2018 .2452$

Hurst, C.J. \& Gerba, C.P. (1980). Stability of simian rotavirus in fresh and estuarine water. Applied and Environmental Microbiology, 39(1), 1-5. DOI: 10.1128/AEM.39.1.1-5.1980.

Iwamoto, M., Ayers, T., Mahon, B.E. \& Swerdlow, D.L. (2010). Epidemiology of seafood-associated infections in the United States. Clinical microbiology reviews, 23(2), 399-411. DOI: 10.1128/CMR.00059-09

Jiang, S., Noble, R. \& Chu, W. (2001). Human adenoviruses and coliphages in urban runoff-impacted coastal waters of Southern California. Applied and Environmental Microbiology, 67(1), 179-184. DOI: 10.1128/AEM.67.1.179-184.2001

Jiang, S.C. (2006). Human adenoviruses in water: occurrence and health implications: a critical review. Environmental Science and Technology, 40(23), 7132-7140. DOI: 10.1021/es0608920

Jiang, S.C., Chu, W. \& He, J.W. (2007). Seasonal detection of human viruses and coliphage in Newport Bay, California. Applied and Environmental Microbiology, 73(20), 6468-6474. DOI: 10.1128/AEM.01370-07

Joshi, M.S., Lole, K.S., Barve, U.S., Salve, D. S., Ganorkar, N.N., Chavan, N.A. \& Gopalkrishna, V. (2019). Investigation of a large waterborne acute gastroenteritis outbreak caused by group B rotavirus in Maharashtra state, India. Journal of medical virology, 91(10), 18771881. DOI: $10.1002 / \mathrm{jmv} .25523$ 
Keller, R., Justino, J.F. \& Cassini, S.T. (2013). Assessment of water and seafood microbiology quality in a mangrove region in Vitória, Brazil. Journal of water and health, 11(3), 573-580. DOI: 10.2166/wh.2013.245

Khora, S.S. (2018). Risk From Viral Pathogens in Seafood. In Diet, Microbiome and Health (pp. 439-481). Academic Press. DOI: 10.1016/B978-0-12-811440-7.00015-6

Kirk, M.D., Pires, S.M., Black, R.E., Caipo, M., Crump, J.A. \& Devleesschauwer, B. (2015). World Health Organization estimates of the global and regional disease burden of 22 foodborne bacterial, protozoal, and viral diseases, 2010: a data synthesis. PLOS Medicine, 12(12), e1001921. DOI: 10.1371/journal.pmed.1001923

Kobayashi, Y., Shimazu, T., Murata, K., Itou, T. \& Suzuki, Y. (2019). An endogenous adeno-associated virus element in elephants. Virus Research, 262, 10-14. DOI: 10.1016/j.virusres.2018.04.015

Kohn, M.A., Farley, T.A., Ando, T., Curtis, M., Wilson, S.A. \& Jin, Q. (1995). An outbreak of Norwalk virus gastroenteritis associated with eating raw oysters: implications for maintaining safe oyster beds. JAMA, 273(6), 466-471. DOI:10.1001/jama.1995.03520300040034

Koopman, J.S., Eckert, E.A., Greenberg, H.B., Strohm, B.C., Isaacson, R. E. \& Monto, A.S. (1982). Norwalk virus enteric illness acquired by swimming exposure. American Journal of Epidemiology, 115(2), 173177. DOI: $10.1093 /$ oxfordjournals.aje.a113288

Koopmans, M., von Bonsdorff, C.H., Vinjé, J., de Medici, D. \& Monroe, S. (2002). Foodborne viruses. FEMS Microbiology Reviews, 26(2), 187 205. DOI: 10.1111/j.1574-6976.2002.tb00610.x

Koopmans, M. \& Duizer, E. (2004). Foodborne viruses: an emerging problem. International Journal of Food Microbiology, 90(1), 23-41. DOI: 10.1016/S0168-1605(03)00169-7

Koopmans, M., Bosch, A. \& Le Guyader, S. (2017). Viruses. In Foodborne Diseases (pp. 289-303). Academic Press. DOI: 10.1016/B978-0-12385007-2.00014-0

Kovač, K., Gutiérrez-Aguirre, I., Banjac, M., Peterka, M., Poljšak-Prijatelj, M., Ravnikar, M., ... \& Raspor, P. (2009). A novel method for concentrating hepatitis $A$ virus and caliciviruses from bottled water. Journal of Virological Methods, 162(1-2), 272-275.

DOI: 10.1016/j.jviromet.2009.07.013

La Rosa, G., Fratini, M., della Libera, S., laconelli, M. \& Muscillo, M. (2012). Emerging and potentially emerging viruses in water environments. Annali Dell'istituto Superiore Di Sanità, 48, 397-406.

DOI: 10.4415/ANN_12_04_07

Lamhoujeb, S.F.I., Ngazoa, S.E. \& Jean, J. (2009) Molecular study of the persistence of infectious human norovirus on foodcontact surfaces. Food and Environmental Virology, 1, 51-56. DOI: 10.1007/s12560-009-9010-0

Le Guyader, F.S., Bon, F., DeMedici, D., Parnaudeau, S., Bertone, A. \& Crudeli, S. (2006). Detection of multiple noroviruses associated with an international gastroenteritis outbreak linked to oyster consumption. Journal of Clinical Microbiology, 44(11), 3878-3882. DOI: 10.1128/JCM.01327-06

Le Guyader, F.S. \& Atmar, R.L. (2007). Viruses in shellfish. Perspectives in medical virology, 17, 205-226. DOI: 10.1016/S0168-7069(07)17010-5

Le Guyader, F.S., Le Saux, J.C., Ambert-Balay, K., Krol, J., Serais, O., Parnaudeau, S. \& Atmar, R.L. (2008). Aichi virus, norovirus, astrovirus, enterovirus, and rotavirus involved in clinical cases from a French oyster-related gastroenteritis outbreak. Journal of Clinical Microbiology, 46(12), 4011-4017. DOI: 10.1128/JCM.01044-08

Lee, R. J. \& Rangdale, R.E. (2008). Bacterial Pathogens in Seafood, Edited by T. Borresen.DOI: 10.1533/9781845694586.3.247

Lees, D., (2000). Viruses and bivalve shellfish. International Journal of Food Microbiology, 59, 81-116. DOI: 10.1016/s0168-1605(00)00248-8

Li, D., Stals, A., Tang, Q.J. \& Uyttendaele, M. (2014). Detection of noroviruses in shellfish and semiprocessed fishery products from a Belgian seafood company. Journal of Food Protection, 77(8), 13421347. DOI: 10.4315/0362-028X.JFP-14-016
Lindberg-Braman, A.M. (1956). Clinical observations on the socalled oyster hepatitis. American Journal of Public Health 53, 1003-1011.

Lizuka, S., Oka, T., Tabara, K., Omura, T., Katayama, K., Takeda, N. \& Noda, M. (2010). Detection of sapoviruses and noroviruses in an outbreak of gastroenteritis linked genetically to shellfish. Journal of Medical Virology, 82(7), 1247-1254. DOI: 10.1002/jmv.21791

Lodder, W.J. \& de Roda Husman, A.M. (2005). Presence of noroviruses and other enteric viruses in sewage and surface waters in The Netherlands. Applied and Environmental Microbiology, 71(3), 1453-1461. DOI: 10.1128/AEM.71.3.1453-1461.2005

Luz, R.B., Staggemeier, R., Fabres, R.B., Soliman, M.C., Souza, F.G. \& Gonçalves, R. (2015). Bioaccumulation of animal adenoviruses in the pink shrimp. Brazilian Journal of Microbiology, 46(3), 715-723. DOI: $10.1590 / S 1517-838246320140323$

Magana-Arachchi, D.N. \& Wanigatunge, R.P. (2020). Ubiquitous waterborne pathogens. In Waterborne Pathogens (pp. 15-42). ButterworthHeinemann. DOI: 10.1016/B978-0-12-818783-8.00002-5

Mattison, K., Karthikeyan, K., Abebe, M., Malik, N., Sattar, S.A., Farber, J.M. \& Bidawid, S. (2007). Survival of calicivirus in foods and on surfaces: experiments with feline calicivirus as a surrogate for norovirus. Journal of Food Protection, 70: 500-503. DOI: 10.4315/0362-028X-70.2.500

McDonnell, S., Kirkland, K.B., Hlady, W.G., Aristeguieta, C., Hopkins, R.S., Monroe, S.S. \& Glass, R.I. (1997). Failure of cooking to prevent shellfish-associated viral gastroenteritis. Archives of Internal Medicine, 157(1), 111-116. DOI: 10.1001/archinte.1997.00440220117015

McLeod, C., Hay B., Grant C., Greening G., \& Day D., (2009). Localization of norovirus and poliovirus in Pacific oysters. Journal of Applied Microbiology, 106: 1220-1230. DOI: 10.1111/j.1365-2672.2008.04091.x

McLeod, C., Polo, D., Le Saux, J C. \& Le Guyader, F.S. (2017). Depuration and relaying: a review on potential removal of norovirus from oysters. Comprehensive Reviews in Food Science and Food Safety, 16(4), 692706. DOI: $10.1111 / 1541-4337.12271$

Moorman, E.A. (2017). Alternative Chemical Disinfection Technologies for Inactivation of Human Norovirus on Surfaces. Msc Thesis, 80p.

Morse, D.L., Guzewich, J.J., Hanrahan, J.P., Stricof, R., Shayegani, M. \& Deibel, R. (1986). Widespread outbreaks of clam-and oyster-associated gastroenteritis. New England Journal of Medicine, 314(11), 678-681. DOI: 10.1056/NEJM198603133141103

Muniain-Mujika, I., Girones, R., Tofiño-Quesada, G., Calvo, M. \& Lucena, F. (2002). Depuration dynamics of viruses in shellfish. International Journal of Food Microbiology, 77(1-2), 125-133

DOI: 10.1016/S0168-1605(02)00324-0

Myrmel, M., Berg, E.M.M., Rimstad, E. \& Grinde, B. (2004). Detection of enteric viruses in shellfish from the Norwegian coast. Applied and $\begin{array}{llll}\text { Environmental Microbiology, } & \text { 70(5), 2678-2684. }\end{array}$ DOI: 10.1128/AEM.70.5.2678-2684.2004

Nakagawa-Okamoto, R., Arita-Nishida, T., Toda, S., Kato, H., Iwata, H. \& Akiyama, M.(2009). Detection of multiple sapovirus genotypes and genogroups in oyster-associated outbreaks. Japanese Journal of Infectious Diseases, 62(1), 63-6.

Namsai, A., Louisirirotchanakul, S., Wongchinda, N., Siripanyaphinyo, U., Virulhakul, P. \& Puthavathana, P. (2011). Surveillance of hepatitis A and $\mathrm{E}$ viruses contamination in shellfish in Thailand. Letters in Applied Microbiology, 53(6), 608-613. DOI: 10.1111/j.1472-765X.2011.03152.x

Oka, T., Wang, Q., Katayama, K. \& Saif, L.J. (2015). Comprehensive review of human sapoviruses. Clinical Microbiology Reviews, 28(1), 32-53. DOI: 10.1128/CMR.00011-14

Parashar, U.D., Hummelman, E.G., Bresee, J.S., Miller, M.A. \& Glass, R.I. (2003). Global illness and deaths caused by rotavirus disease in children. Emerging Infectious Diseases, 9(5), 565. DOI: 10.3201/eid0905.020562

Patwardhan, M.H. (2019). Heat sensitization of human enteric viruses by plant extracts and validation of their thermal inactivation by bacterial surrogates. Master's Thesis, University of Tennessee.

https://trace.tennessee.edu/utk_gradthes/5454 
Pavoni, E., Consoli, M., Suffredini, E., Arcangeli, G., Serracca, L. \& Battistini, R. (2013). Noroviruses in seafood: a 9 -year monitoring in Italy. Foodborne Pathogens and Disease, 10(6), 533-539. DOI: $10.1089 / f p d .2012 .1399$

Pinon, A. \& Vialette, M. (2018). Survival of viruses in water. Intervirology, 61(5), 214-222. DOI: 10.1159/000484899

Prevost, B., Lucas, F.S., Goncalves, A., Richard, F., Moulin, L. \& Wurtzer, S. (2015). Large scale survey of enteric viruses in river and waste water underlines the health status of the local population. Environment International, 79, 42-50. DOI: 10.1016/j.envint.2015.03.004

Quiroz-Santiago, C., Vázquez-Salinas, C., Natividad-Bonifacio, I., BarrónRomero, B.L. \& Quiñones-Ramírez, E.I. (2014). Rotavirus G2P [4] detection in fresh vegetables and oysters in Mexico City. Journal of Food Protection, 77(11), 1953-1959. DOI: 10.4315/0362-028X.JFP-13-426

Rao, V.C., Metcalf, T.G. \& Melnick, J.L. (1986). Development of a method for concentration of rotavirus and its application to recovery of rotaviruses from estuarine waters. Applied and Environmental Microbiology, 52(3), 484-488. DOI: 10.1128/AEM.52.3.484-488.1986

Richards, G.P. (2013). Foodborne and waterborne enteric viruses. In: Fratamico, P.M., Bhunia, A.K., Smith, J.L. (Eds.), Foodborne Pathogens Microbiology and Molecular Biology, Chapter: Foodborne and Waterborne Enteric Viruses. Caister Academic Press, pp. 121-143.

Rivadulla, E., Varela, M.F., Mesquita, J.R., Nascimento, M.S. \& Romalde, J.L. (2019). Detection of hepatitis $E$ virus in shellfish harvesting areas from Galicia (Northwestern Spain). Viruses, 11(7), 618 DOI: 10.3390/v11070618

Rodriguez-Lazaro, D., Cook, N., Ruggeri, F.M., Sellwood, J., Nasser, A. \& Nascimento, M.S.J. (2012). Virus hazards from food, water and other contaminatedenvironments. FEMS Microbiology Reviews, 36, 786-814. DOI :10.1111/j.1574-6976.2011.00306.x

Said, B., ljaz, S., Kafatos, G., Booth, L., Thomas, H.L. \& Walsh, A. (2009). Hepatitis E outbreak on cruise ship. Emerging Infectious Diseases, 15, 1738-1744. DOI: 10.3201/eid1511.091094

Sattar, S.A., Springthorpe, V.S. \& Ansari, S.A., (1994). Rotavirus. In: Hui, Y.H., Gorham, J.R., Murrell, K.D., Cliver, D.O. (Eds.), Foodborne Disease Handbook: Diseases Caused by Viruses, Parasites, and Fungi, vol. 2. Marcel Dekker, New York, NY, pp. 81-111.

Sattar, S.A. (2001). Survival of microorganisms on animate and inanimate surfaces and their disinfection. In: Rutala, W.A. (Ed.), Disinfection, Sterilization and Antisepsis: Principles and Practices in Healthcare Dacilities. Association for Professionals in Infection Control and Epidemiology, Inc, Washington, DC, pp. 195-205. Schwab, K. J., Neill, F. H., Estes, M. K., Metcalf, T. G., \& Atmar, R. L. (1998). Distribution of Norwalk virus within shellfish following bioaccumulation and subsequent depuration by detection using RT-PCR. Journal of Food Protection, 61(12), 1674-1680. DOI: 10.4315/0362-028X-61.12.1674

Schwartzbrod, L. (1995). Effect of human viruses on public health associated with the use of wastewater and sewage sludge in agriculture and aquaculture (No. WHO/EOS/95.19). World Health Organization.

Sharp, T.M., Crawford, S.E., Ajami, N.J., Neill, F.H., Atmar, R.L. \& Katayama, K. (2012). Secretory pathway antagonism by calicivirus homologues of Norwalk virus nonstructural protein p22 is restricted to noroviruses. Virology Journal, 9(1), 1-6. DOI: 10.1186/1743-422X-9-181

Sobsey, M.D. (1989). Inactivation of health-related microorganisms in water by disinfection processes. Water Science and Technology, 21(3), 179195.DOI: $10.2166 /$ wst. 1989.0098

Sooryanarain, H. \& Meng, X.J. (2019). Hepatitis E virus: reasons for emergence in humans. Current opinion in virology, 34, 10-17. DOI: 10.1016/j.coviro.2018.11.006

Souza, D.S.M., Dominot, A.F.Á., Moresco, V. \& Barardi, C.R.M. (2018). Presence of enteric viruses, bioaccumulation and stability in Anomalocardia brasiliana clams (Gmelin, 1791). International Journal of Food Microbiology, 266, 363-371. DOI: 10.1016/i.jifoodmicro.2017.08.004
Springthorpe, S.V., Loh, C.L., Robertson, W.J. \& Sattar, S.A. (1993). In situ survival of indicator bacteria, MS-2 phage and human pathogenic viruses in river water. Water Science and Technology, 27(3-4), 413-420. DOI: 10.2166/wst.1993.0383

Stals, A., Uyttendaele, M., Baert, L, \& Van Coillie, E. (2013). Norovirus transfer between foods and food contact materials. Journal of Food Protection, 76(7), 1202-1209. DOI: 10.4315/0362-028X.JFP-12-392

Tallon, L.A., Love, D.C., Moore, Z.S. \& Sobsey, M.D. (2008). Recovery and sequence analysis of hepatitis a virus from springwater implicated in an outbreak of acute viral hepatitis. Applied and Environmental Microbiology, 74(19), 6158-6160. DOI: 10.1128/AEM.02872-07

Terregino, C. \& Arcangeli, G. (2017). Shellfish and berries: the ready-to-eat food most involved in human norovirus outbreaks. In The Norovirus (pp. 31-47). Academic Press. DOI: 10.1016/B978-0-12-804177-2.00003-8

Teunis, P.F., Moe, C.L., Liu, P., E. Miller, S., Lindesmith, L. \& Baric, R.S. (2008). Norwalk virus: how infectious is it?. Journal of Medical Virology, 80(8), 1468-1476.DOI: 10.1002/jmv.21237

Tozan, E., Duman, P., Elbasan, H.D., Aktepe, Ö., Sezen, F., Temel, F. \& Sucakl, M.B. (2016). A gastroenteritis outbreak investigation, NIGDE city center, March 2014. Türkiye Halk Sağı̆̆ı Dergisi, 14(1), 1-12. DOI: $10.20518 /$ thsd. 83892

Tuladhar, E., Hazeleger, W.C., Koopmans, M., Zwietering, M.H., Duizer, E. \& Beumer, R.R. (2013). Transfer of noroviruses between fingers and fomites and food products. International Journal of Food Microbiology, 167(3), 346-352. DOI: 10.1016/j.ijfoodmicro.2013.09.018

Ueki, Y., Shoji, M., Okimura, Y., Miyota, Y., Masago, Y. \& Oka, T.(2010). Detection of sapovirus in oysters. Microbiology and Immunology, 54(8), 483-486. DOI: 10.1111/j.1348-0421.2010.00239.x

Van der Poel, W. H. (2014). Food and environmental routes of Hepatitis E virus transmission. Current Opinion in Virology, 4, 91-96. DOI: 10.1016/j.coviro.2014.01.006

Vidal, R., Solari, V., Mamani, N., Jiang, X., Vollaire, J. \& Roessler, P.(2005). Caliciviruses and foodborne gastroenteritis, Chile. Emerging Infectious Diseases, 11(7), 1134. DOI: 10.3201/eid1107.041062

Wang, D., Wu, Q., Yao, L., Wei, M., Kou, X. \& Zhang, J. (2008). New target tissue for food-borne virus detection in oysters. Letters in Applied Microbiology, 47(5), 405-409. DOI: 10.1111/j.1472-765X.2008.02445.X

Wang, H., Sikora, P., Rutgersson, C., Lindh, M., Brodin, T. \& Björlenius, B., (2018). Differential removal of human pathogenic viruses from sewage by conventional and ozone treatments. International Journal of Hygiene And Environmental Health, 221(3), 479-488. DOI: 10.1016/j.ijheh.2018.01.012

Ward, R.L., Knowlton, D.R. \& Winston, P.E. (1986). Mechanism of inactivation of enteric viruses in fresh water. Applied and Environmental Microbiology, 52(3), 450-459. DOI: 10.1128/AEM.52.3.450-459.1986

Webb, G.W., Kelly, S. \& Dalton, H.R. (2020). Hepatitis A and Hepatitis E: Clinical and Epidemiological Features, Diagnosis, Treatment, and Prevention. Clinical Microbiology Newsletter, 42(21), 171-179. DOI: 10.1016/j.clinmicnews.2020.10.001

Webby, R.J., Carville, K.S., Kirk, M.D., Greening, G., Ratcliff, R.M. \& Crerar, S.K.(2007). Internationally distributed frozen oyster meat causing multiple outbreaks of norovirus infection in Australia. Clinical Infectious Diseases, 44(8), 1026-1031. DOI: 10.1086/512807

WHO (2006) The world health report 2006: working together for health. World Health Organization. Guidelines for the safe use of wastewater, excreta and greywater. Volume 2: Wastewater use in agriculture. World Health Organisation, Geneva, Switzerland.

WHO (2015). WHO estimates of the global burden of foodborne diseases. Foodborne Disease Burden Epidemiology Reference Group, 20072015

WHO (2016). Hepatitis A. Available at: http://www.who.int/mediacentre/factsheets/fs328/en/ (Accessed 17 October 2016).

Widdowson, M.A., van Doornum, G. ., van der Poel, W. ., de Boer, A., Mahdi, U.,\& Koopmans, M. (2000). Emerging group-A rotavirus and a nosocomial outbreak of diarrhoea. The Lancet, 356(9236), 1161-1162. DOI: 10.1016/S0140-6736(00)02760-4 
Wolff, A., Günther, T., Albert, T., Schilling-Loeffler, K., Gadicherla, A.K. \& Johne, R. (2020). Stability of hepatitis $E$ virus at different $\mathrm{pH}$ values. International journal of food microbiology, 325, 108625. DOI: 10.1016/j.ijfoodmicro.2020.108625

Woods, J.W. Calci, K.R., Marchant-Tambone, J.G. \& Burkhardt III, W. (2016). Detection and molecular characterization of norovirus from oysters implicated in outbreaks in the US. Food Microbiology, 59, 76-84. DOI: 10.1016/j.fm.2016.05.009

Yugo, D.M. \& Meng, X.J. (2013). Hepatitis E virus: foodborne, waterborne and zoonotic transmission. International Journal of Environmental Research and Public Health, 10(10), 4507-4533. DOI: 10.3390/ijerph10104507
Zhang, L., Zhao, N., Sha, J., Wang, C., Jin, X., Amer, S. \& Liu, S. (2016). Virology and epidemiology analyses of global adenovirus-associated conjunctivitis outbreaks, 1953-2013. Epidemiology \& Infection, 144(8), 1661-1672. DOI:10.1017/S0950268815003246

Zhang, L., Li, K., Huang, S., Liu, D., Rehman, M.U., Lan, Y. \& Mehmood, K. (2017). Seroprevalence and risk factors associated with hepatitis $E$ virus infections among people and pigs in Tibet, China. Acta Tropica, 172, 102-106. DOI: 10.1016/j.actatropica.2017.04.033

Zuckerman, J. N. (2003). Hepatitis E and the traveller. Travel Medicine and Infectious Disease, 1, 73- 76.

DOI: $10.1016 /$ S1477-8939(03)00039-5 